\title{
Syntheses and Structures of Two Reduced Open-framework Titanophosphates
}

\author{
Yongnan Zhao, ${ }^{\dagger+*^{*}}$ Jianguo Yu, and Young-Uk Kwon ${ }^{\ddagger *}$ \\ ${ }^{\dagger}$ Institute of Kanostructured Materials, College of Materials Science and Chemical Engineering \& Tianjin Kev Laboratory \\ of Fiber Modification and Functional Fiber, Tianjin Polvechic Universitv. Tianjin 300160. China. "E-mail: zhaovia:263.net \\ -Department of Chemistry \& BK21 School of Chemical Materials Science, Sunghumkwan Cniversin, Sinwon 4+0-746. Korea \\ ${ }^{\star} E$-mail: . wkkoniăskku.edu \\ Received January 7, 2008
}

\begin{abstract}
Using metallic Ti powder as raw materials and 1,2-dianminocyclohexane (DACH) as the trial template, two novel reduced titanophosphate open-structures were hydrothermally isolated by varying the $\mathrm{H}_{3} \mathrm{PO}_{4} / \mathrm{H}_{2} \mathrm{O}$ ratio to adjust the $\mathrm{pH}$ value. TiPO-1 crystallizes in orthorhombic Pbca space group with cell parameters $a=$ $21.956(3)$ A. $b=8.6268(11)$ A. $c=7.2883(9)$ A. $I^{\prime}=1380.5(3) \mathrm{A}^{3}, Z=4$. TiPO-2 crystallizes in triclinic space group $P \overline{1}$ with parameters $a=5.1620(10) \AA, b=8.815(2) \AA . A=10.655(3) \AA A, \alpha=99.45^{\circ} . \beta=102.94^{\circ} . \gamma=$ $91.06^{\circ}, I=465.34 \mathrm{~A}^{3}$. TiPO-1 is constructed by infinite -Ti-O-Ti-O- linkage that is capped by $\mathrm{PO}_{4}$ groups to form a chain structure with protonated DACH molecules occupying the interchain spaces. TiPO-2 represents a rare 3-D reduced titanophosphate with 12-MR channels. The structure of TiPO-2 is a neutral framework with water molecules located in the channels.
\end{abstract}

Key Words : Hydrothermal sỵnthesis. Open-stnucture. Single crysstal structure. Titanophosphate

\section{Introduction}

Transition metal phosphate open-structures are of great interest due to their wide applications in redox catalysis. ionexchange, photochemstry and magnetism..$^{1 \cdot \hat{3}}$ The structural diversity that stemmed from the variable coordination geometry and oxidation states has directed to the extensive expansion of open-framework transition metal phosphates. including $\mathrm{Zn}, \mathrm{Co}$. $\mathrm{Zr}$. Fe. $\mathrm{Ni}$, and $\mathrm{V}$ phosphates. with large dimensions. unique topologies and novel polyhedral connectivities. ${ }^{4.13}$ Titanium phosphates have shown important properties in materials science, such as the second hanmonic generation crystal $\mathrm{KTiOPO}_{4}$, the excellent ion-exchange and adsorptive properties of layered $\alpha-\operatorname{Ti}\left(\mathrm{HPO}_{4}\right)_{2}=\gamma-\operatorname{Ti}\left(\mathrm{H}_{2} \mathrm{PO}_{4}\right)$ $\left(\mathrm{PO}_{4}\right) \cdot \mathrm{H}_{2} \mathrm{O}$, and the NASICON-type $\mathrm{MTi}_{2}\left(\mathrm{PO}_{4}\right)_{3}$ as fast ionic conductors or low thermal expansion ceramics. ${ }^{1+18}$ However, the open-structured titanophosphates are still limited in literature up to date. $\mathrm{Rb}_{2} \mathrm{Ti}_{3} \mathrm{O}_{2}\left(\mathrm{PO}_{4}\right)_{2}\left(\mathrm{HPO}_{4}\right)_{2}$ was the first synthetic example with 12-ring channels for the persuit of new KTP-related compound ${ }^{19}$ Two layerd structures and an anhydrous form of $\gamma \cdot \mathrm{Ti}\left(\mathrm{H}_{-} \mathrm{PO}_{4}\right)\left(\mathrm{PO}_{4}\right) \cdot \mathrm{H}_{2} \mathrm{O}$ were reported in the early $1990 \mathrm{~s} \cdot{ }^{3(1)}$ Clearfield and co-workers contributed three porous structures. which contain monomeric, dimeric and trimeric $\mathrm{TiO}_{6}$ octahedra respectively. ${ }^{23}$ Several new titanophosphate and titanophosphonate compounds were isolated by Ferey's group and Pang's group in the past few years. ${ }^{2+29}$ The first templated microporous mixvalent $\mathrm{Ti}^{\mathrm{III}} \mathrm{Ti}^{\mathrm{IV}}$ titanophosphate were reported by Sevov. ${ }^{3 \mathrm{i}}$ Of the known titanophosphate compounds. reduced materials are rare and interesting for catalytic, magnetic properties. Recently, two reduced titanium gallophosphates were synthesized. including a novel microporous phase possessing 10-MR channels and reversible oxidation state of $\mathrm{Ti}^{\mathrm{III}}$ and $\mathrm{Ti}^{\mathrm{IV}}$, showing potential redox catalytic property. ${ }^{31,32} \mathrm{~A}$ new mixed valent titanophosphate open-structure with intresecting 12-ring channels. TJPU-2. was recently reported by using zinc cations as the mineralizer. By Using 1,2-diaminocyclohexane $(\mathrm{DACH})$ as the trial template. two new reduced titanophosphate open-structures $\left[\mathrm{H}_{2} \mathrm{DACH}\right]_{0}=\left[\mathrm{TiO}\left(\mathrm{HPO}_{4}\right)_{2}\right]$ $\mathrm{H}_{2} \mathrm{O}$ (denoted as TiPO-1) and $\left[\mathrm{Ti}^{\mathrm{III}} \mathrm{Ti}_{1}{ }^{\mathrm{IV}}\left(\mathrm{H}_{2} \mathrm{O}\right)_{0} 5\left(\mathrm{PO}_{4}\right)_{2-}\right.$ $\left(\mathrm{HPO}_{4}\right)_{1}$ s] $\mathrm{H}_{2} \mathrm{O}$ (denoted as TiPO-2) were isolated. Here we report their syntheses and structures.

\section{Experimental}

TiPO-1 was synthesized from $0.25 \mathrm{~g}$ metallic Ti powder. 3 $\mathrm{mL} \mathrm{H}_{3} \mathrm{PO}_{4} .7 \mathrm{~mL} \mathrm{H}_{2} \mathrm{O}$ and $\mathrm{l} \mathrm{g} \mathrm{DACH}$ as a template Typically. Ti powder, $\mathrm{H}_{3} \mathrm{PO}_{4}$ and water was sealed in an autoclave and reacted at $180^{\circ} \mathrm{C}$ for two days. After cooled to room temperature. DACH was injected and stirred to homogeneity. The final mixture with $\mathrm{pH}$ value of 2.5 was heated at $180^{\circ} \mathrm{C}$ for 8 days. $1.39 \mathrm{~g}$ blue plate-like crystals precipitated at the bottom with $68 \%$ yield based on titanium metal. A similar procedure was performed for isolating compound TiPO-2 with different compositions of $0.25 \mathrm{~g}$ metallic Ti powder. $7 \mathrm{~mL} \mathrm{H}_{3} \mathrm{PO}_{4}, 3 \mathrm{~mL} \mathrm{H}_{2} \mathrm{O}$ and $\mathrm{I} \mathrm{g}$ DACH. The $\mathrm{pH}$ value of the starting mixture for TiPO-2 was -0.25 . Reddish brown polyhedral crystals fonmed with very low yield. These crystals are stable in air for several months. The blue and brown colours of TiPO-n indicate the existence of $\mathrm{Ti}^{3-}$ species in these compounds. The Ti:P ratio were measured by energy dispersive X-ray analysis on three cry stals of each sample with the average results of 10.78 .5 .97 for TiPO-1 and 10.56:6.24 for TiPO-2 respectively, which were close to the theoretical values.

Single crystals of TiPO-1 and TiPO-2 were mounted on glass fibers. The data were collected on a Siemens Smart CCD diffractometer equipped with a normal focus, $2.4 \mathrm{KW}$ 
Table 1. Crystal data and structural refunement for TiPO-l and $\mathrm{TiPO}-2$

\begin{tabular}{|c|c|c|}
\hline Compound Name & TiPO-1 & TiPO-2 \\
\hline Fonmula weight & 390.99 & 1237.38 \\
\hline Temperature & $293(2) \mathrm{K}$ & \\
\hline $\begin{array}{l}\text { Crystal system, } \\
\text { space group }\end{array}$ & orthorhombic, $\mathrm{Pbca}$ & triclinic, $P \bar{l}$ \\
\hline$a, \alpha$ & $21.956(3) \AA, 90^{\circ}$ & $5.1620(10) \AA, 99.45^{\circ}$ \\
\hline$b, \beta$ & $8.6268(11) \AA, 90^{\circ}$ & $8.815(2) \AA, 102.94^{\circ}$ \\
\hline$c, \gamma$ & $7.2883(9) \AA, 90^{\circ}$ & $10.655(3) \AA, 91.06^{\circ}$ \\
\hline Volume & $1380.5(3) \AA 3$ & 465.34 \\
\hline $\begin{array}{l}\text { Z, Calculated density } \\
\left(\mathrm{gem}^{-3}\right)\end{array}$ & $4,1.824$ & $1,2.379$ \\
\hline $\begin{array}{l}\text { Absorption coefficient } \\
\left(\mathrm{mm}^{-1}\right)\end{array}$ & 0.904 & 1.800 \\
\hline $\begin{array}{l}\text { Theta range for data } \\
\text { collection }\end{array}$ & $1.86^{\circ}$ to $28.31^{\circ}$ & $1.99^{\circ}$ to $25.00^{\circ}$ \\
\hline $\begin{array}{l}\text { Reflections collected/ } \\
\text { unique }\end{array}$ & $\begin{array}{l}8373 / 3270 \\
{[R i n t=0.0247]}\end{array}$ & $\begin{array}{l}1808 / 1609 \\
{[R i n t=0.0695]}\end{array}$ \\
\hline Goodness of fit & 1.090 & 1.069 \\
\hline $\mathrm{R}$ indices (all data) & $\begin{array}{l}R 1=0.0663 \\
w R 2=0.1478\end{array}$ & $\begin{array}{l}R \mathrm{I}=0.0868 \\
\mathrm{w} R 2=0.1978\end{array}$ \\
\hline
\end{tabular}

sealed tube X-ray source. The structure was solved by directed method. The titanium and phosphorous and oxygen atoms were first located and the carbon. nitrogen and part of hydrogen atoms were found in the final difference Fourier maps. Structure solution and refinement were performed by using SHELXTL (Ver. 5.01) progran. Crystal data and details of structure refinement are given in Table 1 . The atomic positions are listed in Table 2 and Table 3 for TiPO-1 and $\mathrm{TiPO}-2$ respectively.

\section{Results and Discussion}

TiPO-I and TiPO-2 were synthesized by varying the $\mathrm{H}_{3} \mathrm{PO}_{4} /$ $\mathrm{H}_{2} \mathrm{O}$ ratio to adjust the $\mathrm{pH}$ value of the starting mixtures. The speciation of titanium in solution has been claimed depending on several factors. In the present system. the $\mathrm{pH}$ value play's the key role. Studies on the hydrolysis of $\mathrm{Ti}^{\hat{3+}}$ cation indicate the tendency of formation $\mathrm{Tit}_{3}(\mathrm{OH})_{2}{ }^{+-}$dimer and containing significant amount of $\mathrm{Ti}^{4-}$ cations in the system even at very low $\mathrm{pH}$ value ${ }^{3 \hat{3}}$ This makes it more difficult to understand the hydrolysis behavior and the formation mechanism of TiPO-n. Ferey's group has ș'stematically' investigated the deprotonation of $\mathrm{Ti}^{+1}$ to study the formation mechanism of $\mathrm{Ti}^{\mathrm{IV}}$ titanophosphates. ${ }^{34}$ Deprotonation lead to condensation through phosphate bridges. The dimensionality of the crystal is affected by the protonation of phosphate group. When the acidity decreases. condensation of $\mathrm{TiO}_{6}$ occurs through the formation of $\mathrm{Ti}-\mathrm{O}-\mathrm{Ti}$ bond including clusters and chains. The phenomenon in the formation of TiPO-n is similar to Ferey's observations. which suggests the hydroly sis of $\mathrm{Ti}^{4+}$ cations at different acidity directed the structural variation of TiPO-n. The comparison between the experimental and simulated powder XRD patterns indicates both of TiPO-1 and TiPO-2 are isolated as pure phase
Table 2. Atomic coordinates and equivalent isotropic displacement parameters for TiPO-1

\begin{tabular}{|c|c|c|c|c|}
\hline & $\mathrm{s}$ & $y$ & 2 & Ueq \\
\hline PI & $0.39129(4)$ & $0.34864(10)$ & $0.2087(4)$ & $0.0164(2)$ \\
\hline $\mathrm{P} 2$ & $0.43029(4)$ & $0.76983(10)$ & $0.2099(4)$ & $0.0155(2)$ \\
\hline Til & $0.49836(8)$ & $0.5002(2)$ & $0.4689(3)$ & $0.0257(2)$ \\
\hline Ol & $0.36582(14)$ & $0.1796(4)$ & $0.2059(12)$ & $0.0240(7)$ \\
\hline $\mathrm{O} 2$ & $0.33555(12)$ & $0.4518(3)$ & $0.2120(12)$ & $0.0296(7)$ \\
\hline 03 & $0.4309(2)$ & $0.3747(8)$ & $0.0356(7)$ & $0.0264(13)$ \\
\hline 04 & $0.4301(2)$ & $0.3697(8)$ & $0.3771(6)$ & $0.0226(13)$ \\
\hline 05 & $0.43957(12)$ & $0.9418(3)$ & $0.2109(12)$ & $0.0250(6)$ \\
\hline 06 & $0.4587(3)$ & $0.6925(7)$ & $0.0359(7)$ & $0.0246(13)$ \\
\hline 07 & $0.4539(3)$ & $0.6953(7)$ & $0.3807(7)$ & $0.0239(13)$ \\
\hline 08 & $0.35963(13)$ & $0.7430(4)$ & $0.2040(13)$ & $0.0310(7)$ \\
\hline 09 & $0.53654(12)$ & $0.4796(3)$ & $0.2084(10)$ & $0.0209(5)$ \\
\hline ow & $0.2384(2)$ & $0.5427(5)$ & $0.0065(8)$ & $0.0500(15)$ \\
\hline HWA & 0.2119 & 0.5584 & 0.1113 & 0.060 \\
\hline $\mathrm{HWB}$ & 0.2117 & 0.5584 & -0.0981 & 0.060 \\
\hline $\mathrm{Nl}$ & $0.53937(15)$ & $0.1245(4)$ & $0.2057(13)$ & $0.0230(7)$ \\
\hline $\mathrm{Hll}$ & 0.5112 & 0.0503 & 0.2071 & 0.034 \\
\hline $\mathrm{H} 12$ & 0.5357 & 0.1799 & 0.1033 & 0.034 \\
\hline $\mathrm{Hl} 3$ & 0.5343 & 0.1860 & 0.3025 & 0.034 \\
\hline N2 & $0.6514(2)$ & $0.3148(5)$ & $0.226(2)$ & $0.0551(19)$ \\
\hline $\mathrm{H} 21$ & 0.6896 & 0.3493 & 0.2221 & 0.083 \\
\hline $\mathrm{H} 22$ & $0.63+4$ & 0.3433 & 0.3321 & 0.083 \\
\hline $\mathrm{H} 23$ & 0.6303 & 0.3548 & 0.1336 & 0.083 \\
\hline $\mathrm{Cl}$ & $0.6513(2)$ & $0.1510(6)$ & $0.213(3)$ & $0.061(2)$ \\
\hline $\mathrm{HlA}$ & 0.6498 & 0.1580 & 0.0791 & 0.073 \\
\hline $\mathrm{C} 2$ & $0.6003(2)$ & $0.0538(6)$ & $0.213(3)$ & $0.085(3)$ \\
\hline $\mathrm{H} 2 \mathrm{~A}$ & 0.6015 & 0.0501 & 0.0783 & 0.103 \\
\hline $\mathrm{C} 3$ & $0.6023(2)$ & $-0.1091(5)$ & $0.219(2)$ & $0.0423(15)$ \\
\hline HBA & 0.5762 & -0.1488 & 0.1228 & 0.051 \\
\hline $\mathrm{H} 3 \mathrm{~B}$ & 0.5848 & -0.1418 & 0.3354 & 0.051 \\
\hline $\mathrm{C} 4$ & $0.6635(2)$ & $-0.1847(5)$ & $0.2003(17)$ & $0.0351(13)$ \\
\hline $\mathrm{H} 4 \mathrm{~A}$ & 0.6720 & -0.2013 & 0.0712 & 0.042 \\
\hline $\mathrm{H} 4 \mathrm{~B}$ & 0.6626 & -0.2852 & 0.2599 & 0.042 \\
\hline $\mathrm{C} 5$ & $0.71+1(3)$ & $-0.0881(8)$ & $0.2836(10)$ & $0.0428(16)$ \\
\hline H5A & 0.7532 & -0.1359 & 0.2578 & 0.051 \\
\hline $\mathrm{H} 5 \mathrm{~B}$ & 0.7091 & -0.0832 & 0.4157 & 0.051 \\
\hline $\mathrm{C} 6$ & $0.71264(19)$ & $0.0765(6)$ & $0.2029(17)$ & $0.0319(10)$ \\
\hline $\mathrm{H} 6 \mathrm{~A}$ & $0.7+17$ & 0.1405 & 0.2683 & 0.038 \\
\hline $\mathrm{H} 6 \mathrm{~B}$ & 0.7253 & 0.0720 & 0.0755 & 0.038 \\
\hline $\mathrm{Hl}$ & $0.383(3)$ & $0.124(7)$ & $0.179(12)$ & $0.03(2)$ \\
\hline $\mathrm{H} 2$ & $0.3505(18)$ & $0.653(5)$ & $0.251(6)$ & $0.000(11)$ \\
\hline
\end{tabular}

(Figure 1).

Single crystal structure refinement reveals that TiPO-1 crystallizes in the orthorhombic space group $\mathrm{Pbca}$. The asy'mmetric unit of TiPO-l contains 21 non-hydrogen atoms. one Ti, two $\mathrm{P}$, ten $\mathrm{O}$, two $\mathrm{N}$ and six $\mathrm{C}$ atoms (Figure 2). The $\mathrm{Ti}$ atom is hexagonally coordinated by six $\mathrm{O}$ atoms with the bond lengths of $1.914(7)-2.083(7) \mathrm{A}$. The bond angles range from $87.07(18)^{\circ}$ to $179.63(12)^{\circ}$. Four coordinated oxygen atoms of $\mathrm{Ti}$ are colmected to $\mathrm{Pl}[\mathrm{O} 3, \mathrm{O}]$ and $\mathrm{P} 2[\mathrm{O}, \mathrm{O}$, atoms. The $\mathrm{O} 9$ atom bridges the titanium atoms into an infinite linear -Ti-O-Ti-O-Ti- linkage with $\mathrm{O} 9-\mathrm{Ti}-\mathrm{O} 9$ bond 
Table 3. Atomic coordinates and equivalent isotropic displacement parameters for $\mathrm{TiPO}-2$

\begin{tabular}{lllll}
\hline & \multicolumn{1}{c}{$\mathrm{x}$} & \multicolumn{1}{c}{$y$} & \multicolumn{1}{c}{$z$} & \multicolumn{1}{c}{$\mathrm{U}$} \\
\hline Til & 0.5000 & 0.5000 & 0.0000 & $00111(5)$ \\
Ti2 & $-0.1390(2)$ & $1.06236(14)$ & $0.20608(12)$ & $0.0095(4)$ \\
P3 & $-0.6046(3)$ & $1.3098(2)$ & $0.23393(18)$ & $0.0105(5)$ \\
P4 & $0.2983(3)$ & $0.8492(2)$ & $0.09600(18)$ & $0.0090(5)$ \\
P5 & $0.0580(9)$ & $0.9158(5)$ & $0.4735(4)$ & $0.0241(10)$ \\
01 & $0.1560(11)$ & $0.4293(6)$ & $-0.1497(5)$ & $0.0216(12)$ \\
02 & $0.3519(12)$ & $0.3742(7)$ & $0.1077(6)$ & $0.0308(15)$ \\
03 & $0.3031(11)$ & $0.6750(6)$ & $0.0692(6)$ & $0.0247(14)$ \\
04 & $-0.5899(17)$ & $1.4448(8)$ & $0.3509(7)$ & $0.0451(19)$ \\
05 & $-0.3436(11)$ & $1.2338(6)$ & $0.2614(6)$ & $0.0237(13)$ \\
06 & $0.1658(10)$ & $1.2013(7)$ & $0.2344(6)$ & $0.0246(14)$ \\
07 & $-0.2449(10)$ & $1.0834(7)$ & $0.0306(5)$ & $0.0221(13)$ \\
08 & $-0.4370(10)$ & $0.9178(6)$ & $0.1853(5)$ & $0.0146(11)$ \\
09 & $0.0732(10)$ & $0.8889(6)$ & $0.1660(5)$ & $0.0154(11)$ \\
010 & $-0.0338(10)$ & $1.0371(6)$ & $0.3897(4)$ & $0.0179(12)$ \\
010 & $0.0338(10)$ & $0.9629(6)$ & $0.6103(4)$ & $0.0179(12)$ \\
011 & $-0.115(4)$ & $0.7662(13)$ & $0.4127(14)$ & $0.065(6)$ \\
012 & $0.338(3)$ & $0.857(3)$ & $0.4609(18)$ & $0.114(11)$ \\
OW1 & 0.0000 & 0.5000 & -0.3000 & $0.118(7)$ \\
OW2 & $-0.347(8)$ & $0.705(3)$ & $0.386(2)$ & $0.132(13)$ \\
\hline & & & &
\end{tabular}
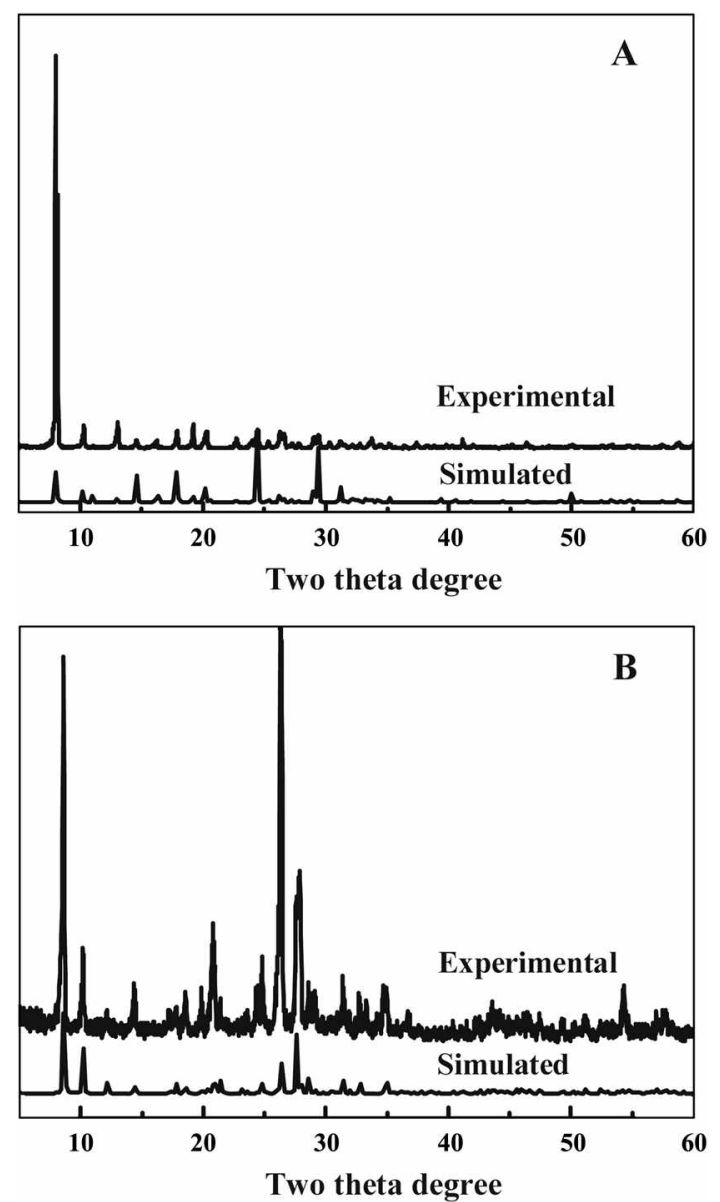

Figure 1. The experimental and simulated XRD pattens of TiPO-1 (A) and TiPO-2 (B).

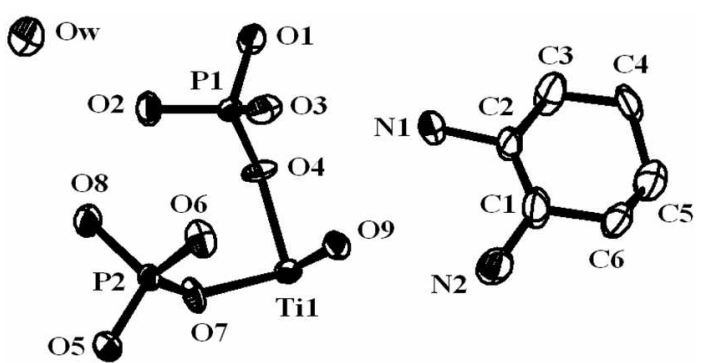

Figure 2. The ORTEP view of TiPO-1 with the labelling scheme.

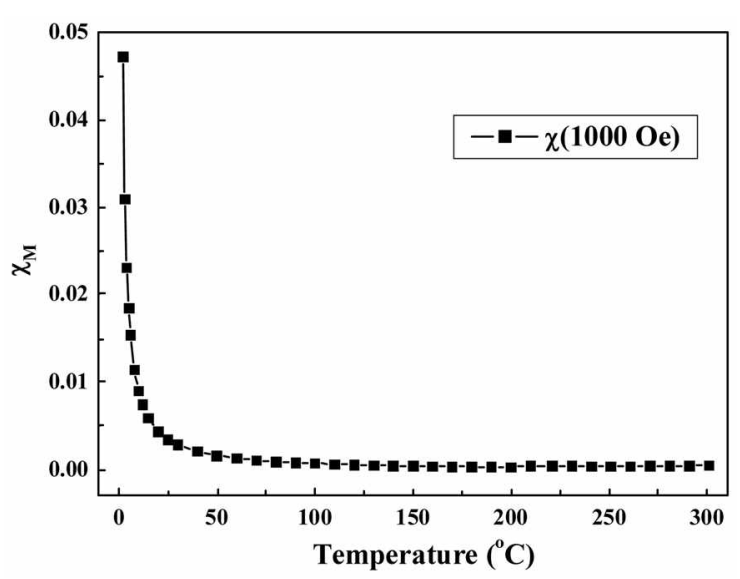

Figure 3. The magnetic curve of TiPO-1.

angel of $179.63^{\circ}$. The $\mathrm{PO}_{4}$ groups have the geometry of the monophosphate with the bond lengths ranging from $1.494(6) \AA$ to $1.569(3) \AA$ and the bond angles of $105.06(17)$ $112.4(4)^{\circ}$. Two oxygen atoms of each $\mathrm{P}$ atom are joint to $\mathrm{Ti}$ atoms. with the rest pending to the interchain spaces. $\mathrm{Ol}$ of $\mathrm{Pl}$ and $\mathrm{O} 8$ of $\mathrm{P} 2$ are hydroxy groups with the enlongated $\mathrm{P}$ $\mathrm{O}$ distances [Pl-Ol. 1.562(3) Å: P2-O8. $1.569(3) \AA]$. Magnetic curve was measured to determine the oxidation state of Ti in TiPO-1. The experimental curve (Figure 3) is fitted with $\chi_{\mathrm{m}}=C_{\mathrm{m}} /(T-\theta)+\mathrm{TIP}$, where $C_{\mathrm{m}}$ and $\theta$ are the Curie and Weiss constants respectively, and TIP is the temperature independent paramagnetism orignated from mixing of low-lying empty' states. The Curie constant indicates the magnetic moments of $0.867 \mu$ p. This is consistent with half unpaired electron per formula unit. Bond valence sum calculation gives the oxidation state of Ti atoms of 3.51 . which is in agreement with the magnetic result. For the charge balance. half proton is required. Hence TiPO-l is fomulated as $\left[\mathrm{H}_{2} \mathrm{DACH}\right] \mathrm{H}_{1,5}\left[\mathrm{TiO}\left(\mathrm{HPO}_{4}\right)_{2}\right] \mathrm{H}_{2} \mathrm{O}$.

$\mathrm{TiO}_{6}$ octahedral and $\mathrm{PO}_{4}$ tetrahedral are held togethor forming an anionic $\left[\mathrm{TiO}\left(\mathrm{HPO}_{4}\right)_{2}\right]^{-2.5}$ chain structure (Figure 4). The negative charges are compensated by protonated $\mathrm{DACH}$ molecules. The $\mathrm{TiO}_{6}$ octahedral is slightly distorted along the chain direction with the difference of $\mathrm{Ti}-\mathrm{O}$ bond lengths [Ti-O9\#1 and Ti-O9] of $0.169 \mathrm{~A}$. which is different from those in compounds JTP-A [a Ti ${ }^{\mathrm{IV}}$ titanophosphate chain with similar topology of TiPO-1]. TP-Jl and KTP type structures. The differences maybe originate from the existence of $\mathrm{T}^{\mathrm{III}}$. The interchain spaces are filled with protonated $\mathrm{DACH}$ and water molecules. The structure of TiPO-I is 

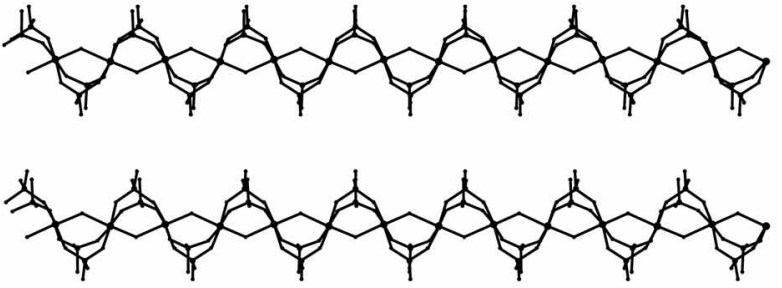

$a$

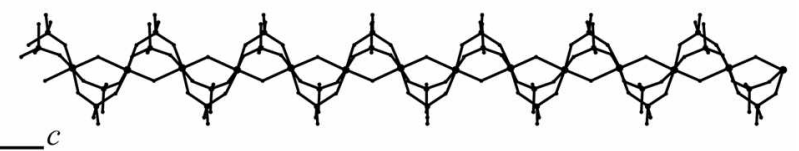

Figure 4. Structure of TiPO-l along $[010]$ direction. The $\mathrm{H}$ atoms, water and DACH molecules are omitted for clarity.

stabilized by complex H-bonds [N1-H $\cdots$ O5. $2.70 \mathrm{~A}$. Nl-H

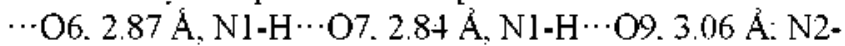

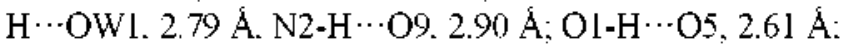
$\mathrm{O} 8-\mathrm{H} \cdots \mathrm{O} 2,2.57 \AA$.].

TiPO-1 is a structural analogne to AIPO-CJI0 (a chain structure of fluoroaluminophosphate), ${ }^{3 \vdots 36} \mathrm{LiNa}-\mathrm{HAl}\left(\mathrm{PO}_{4}\right)=$ $(\mathrm{OH})$. $\mathrm{Na} 4 \mathrm{Al}\left(\mathrm{PO}_{4}\right)_{2}(\mathrm{OH})$ and $\mathrm{Na}_{3} \mathrm{Al}(\mathrm{OH})\left(\mathrm{HPO}_{4}\right)\left(\mathrm{PO}_{4}\right),{ }^{37.38}$ $\mathrm{T}^{\mathrm{IV}}$ titanophosphate JTP-A and mineral tancoite. ${ }^{28}$ Sinilar chain structures also occur in two gallophosphates. ${ }^{3 !}$ These reveal some relationship between alumino-, gallophosphate and titanophosphate. In JTP-A. the $-\mathrm{Ti}^{\mathrm{IV}}-\mathrm{O} \cdot \mathrm{T}^{\mathrm{IV}}-\mathrm{O}$ - linkage is in cis-cis-trans configuration. Due to the flexibility of ethylenedianine molecules. the bending of the chains gives rise to helices. However. the $\mathrm{TiO}_{6}$ octahedral in $\mathrm{TiPO}-\mathrm{I}$ are all trons-linked similar to the-Ti-O-Ti-O- linkages in TP-Jl and $\alpha-\mathrm{NaTiOPO}_{4}{ }^{24}$ The rigid $\mathrm{DACH}$ template directs to a linear chain structure.

Compound TiPO-2 crystallizes in the triclinic space group $P \overline{1}$. The asymmetric unit contains eighteen non-hydrogen atonis. two $\mathrm{Ti}$, three $\mathrm{P}$ and thirteen $\mathrm{O}$ (Figure 5). Both of the two Ti atoms are coordinated by six $\mathrm{O}$ atoms with the bond lengths of 1.974(6)-2.109(6) A for Til and 1.863(6)$1.972(5)$ A for Ti2 respectively. Four oxygen atoms attached to Til are joints to $\mathrm{P} 3$ and $\mathrm{P} 4$ atoms. The rest of two oxygen atoms belong to coordinated water molecules with elongated Ti-O bond of $2.114 \AA$. All of the oxygen atoms attached to $\mathrm{Ti} 2$ bond to $\mathrm{P}$ atoms. The $\mathrm{PO}_{4}$ groups have the geometry of the monophosphate with the bond lengths ranging from $1.479(6)$ to $1.570(9) \mathrm{A}$ and the bond angles of $98.3(13)-$ $117.8(8)^{\circ} . \mathrm{O} 4$ of $\mathrm{P} 3$ and $\mathrm{Oll}$ and $\mathrm{Ol} 2$ of $\mathrm{P} 5$ are hydroxy

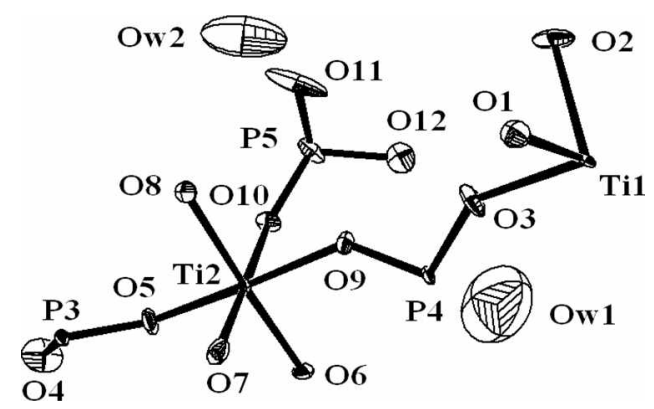

Figure 5. The ORTEP plot of TiPO-2 with the labeling scheme.

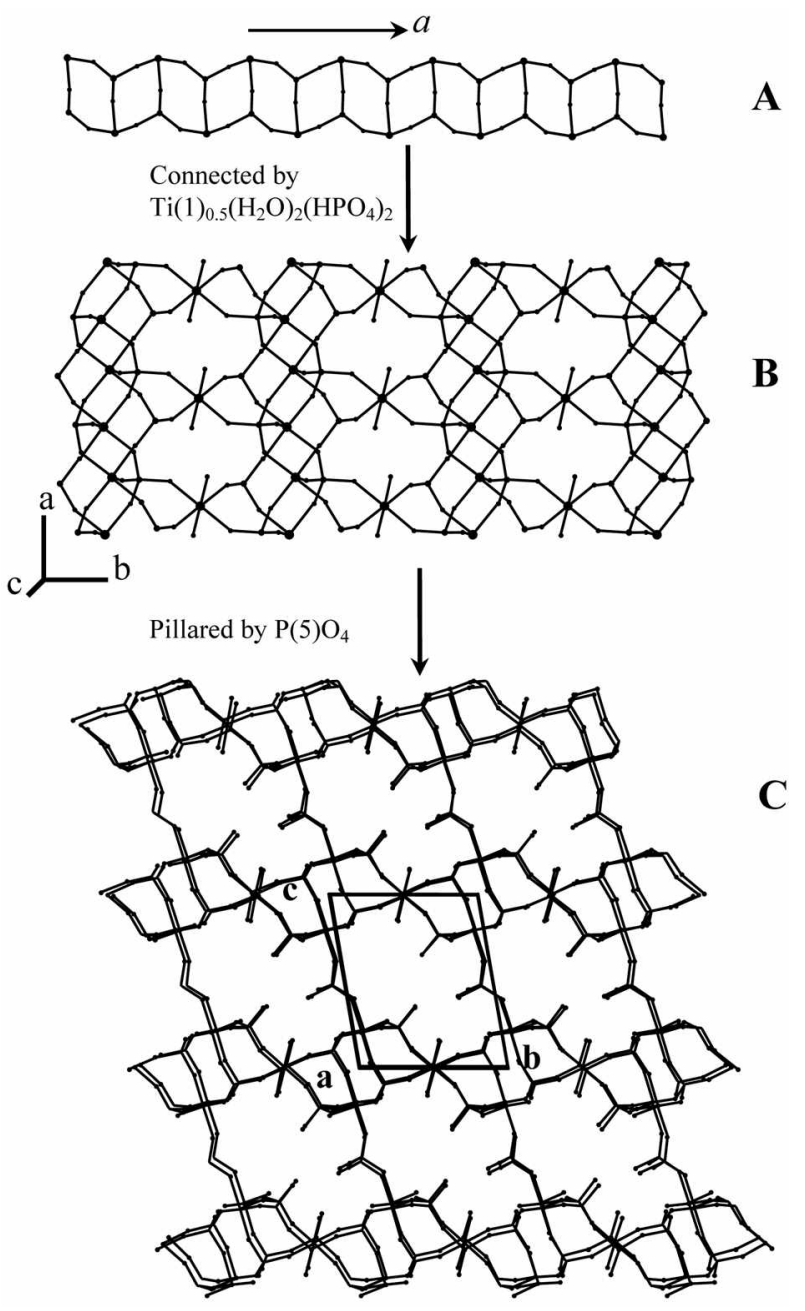

Figure 6. Illustration of the formation scheme of TiPO-2 showing the $4-M R$ chains $(A)$, the 8-MR charnels along $c$ direction $(B)$ and 12-MR channels along $a$ direction (C).

groups with the elongated P-O bond lenths. Bond valence sum calculation shows that the oxidation state of $\mathrm{Ti}$ atoms are 3.23 for Til and 4.17 for Ti2 respectively. The ratio of $\mathrm{Ti}^{\mathrm{III}}$ to $\mathrm{Ti}^{\mathrm{lY}}$ is 0.5 . Hence, TiPO-2 can be formulated as $\left[\mathrm{Ti}_{1,5}{ }^{\mathrm{III}}\left(\mathrm{H}_{2} \mathrm{O}\right)_{2} \mathrm{Ti}^{\mathrm{IV}}\left(\mathrm{PO}_{4}\right)\left(\mathrm{HPO}_{4}\right)\left(\mathrm{H}_{2} \mathrm{PO}_{4}\right)_{1.5}\right] \cdot \mathrm{H}_{2} \mathrm{O}$.

The extended structure of TiPO-2 is a neutral network constructed by $\mathrm{TiO}_{6}$ and $\mathrm{PO}_{4}$ groups without $\mathrm{Ti}-\mathrm{O}$-Ti and $\mathrm{P}$ O-P linkages. The structure could be illustrated as the following steps as shown in Figure 6. $\mathrm{Ti}_{2} \mathrm{O}_{6}$ and $\mathrm{P}_{4} \mathrm{O}_{4}$ groups fuse together to form 4-MR rings. The edge linking of these 4-MR rings generates infuite chains ruming along $a$ direction. These chains are connected by $\left[\operatorname{Til}\left(\mathrm{H}_{2} \mathrm{O}\right)_{2}=\right.$ $\left.\left(\mathrm{HPO}_{4}\right)_{2}\right]$ bridges. giving rise to a layer structure in $a b$ plane with 8-MR windows along $c$ axis. Using $\mathrm{P5O}_{4}$ groups as pillars. stacking of these layers produces a complex 3-D tunnel architecture with 12-MR channels along $a$ direction (Figure 6C) and 8-MR tunnels along $b$ directions (Figure 7). The 12-MR channels show a diemunsion of $10.6 \AA(08-09)$ $\times 6.6 \mathrm{~A}(\mathrm{O} 5-06)$. The channel spaces are occupied by water molecules.

The thermogravimetric curves of TiPO-1 and TiPO-2 are 


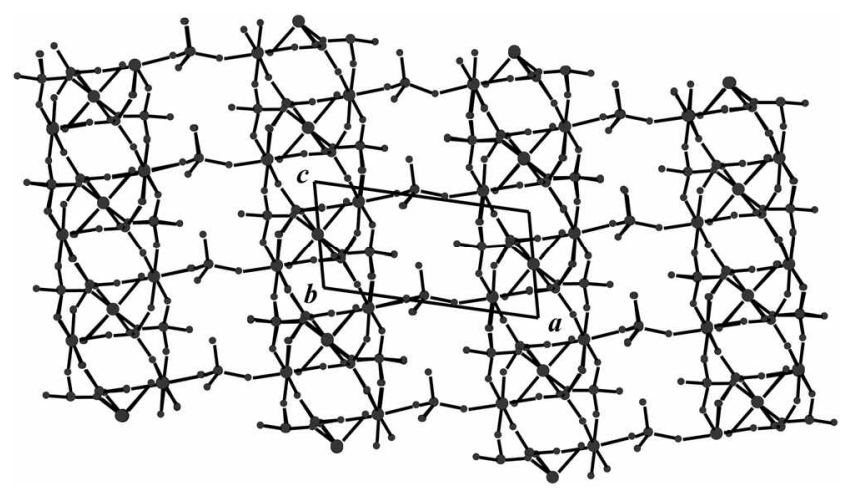

Figure 7. Structure of TiPO-2 along $b$ direction showing the 8-MR ring chanuels.
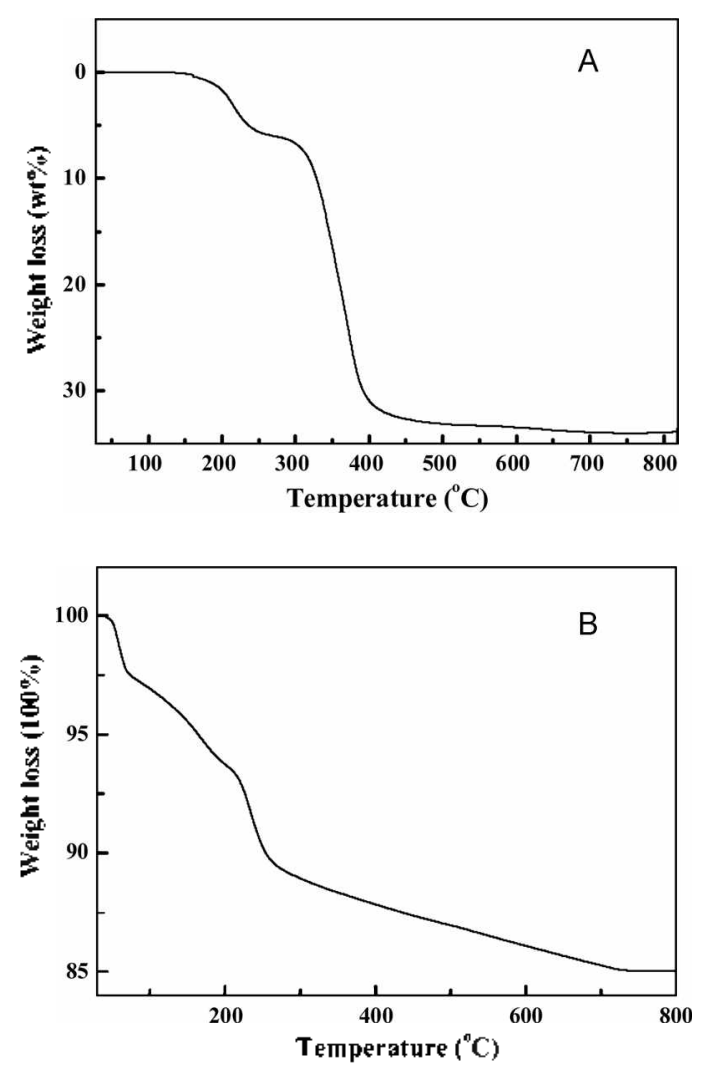

Figure 8. The TG curves for TiPO-1 (A) and TiPO-2 (B).

shown in Figure 8. Thermogravimetric analysis of TiPO-1 shows a two-step weight loss. The $6.05 \%$ weight loss at 150 $290{ }^{\circ} \mathrm{C}$ is assigned to the emission of water. $27.35 \%$ of mass loss between $290{ }^{\circ} \mathrm{C}$ and $600{ }^{\circ} \mathrm{C}$ is attributed to the loss of DACH molecules and hydroxyl groups. Heating TiPO-L at $220^{\circ} \mathrm{C}$ for two hours results in deep blue crystals. Indicated by the powder XRD data, the first peak of the heated crystal slightly shifted to low angel compared with the as-prepared sample. Attempts on determining the structure of the annealed sample failed. The total $14.96 \%$ weight loss of TiPO-2 between $40^{\circ} \mathrm{C}$ and $800^{\circ} \mathrm{C}$ was in agreement with the calculated result of $15.2 \%\left[2.4 \% .40-70{ }^{\circ} \mathrm{C} .4 .0 \%, 70\right.$ $200^{\circ} \mathrm{C} ; 8.56 \% .200-720^{\circ} \mathrm{C}$ ]. These mass losses are stemmed from removing water molecules.

\section{Conclusions}

The present study shows that various topologies of titanophosphates could be formed by adjusting the starting compositions under the assistance of organoamine. Two novel mix-valent titanophosphate open-structures have been successfully isolated under hydrothermal conditions. The structures varied from I-D chain of TiPO-I to 3-D tunnel structure of TiPO-2 by changing the $\mathrm{H}_{3} \mathrm{PO}_{4} / \mathrm{H}_{2} \mathrm{O}$ ratio. $\mathrm{TiPO}-2$ is a rare example of three-dimensional reduced titanophosphate with intersecting 12-MR apertures, which indicates that large dimensions could be accessed in the family of reduced titanophosphates.

Acknowledgements. This Project sponsored by SRF for ROCS. SEM. Nature Science Foundation of Tianjin (Grant No. 05YFJMJC 13500). Center for nanotubes and nanostructured composites, Sungkyunkwan University.

\section{References}

1. Muller. A.: Renter. H.: Dillinger. S. Angew Chent. Int. Ed. Engl. 1995. 34. 2328.

2. Ferey G Chent Mater 2001. 13. 3084

3. Cheetham. A. K.: Ferey, G.: Loiseau, T. Angew. Chem. Int. Ed. 1999. 38,3268 .

4. Rao. C. N. R.; Natarajan. S.: Choudhury, A.; Neeraj. S.: Ayi. A. A Ace. (hem. Res. 2001. 34. 80.

5. Riou-Catellec. M.: Riou. D.: Ferey. G. Inorg. Chem. Acta 1999. 291.317.

6. Jung, K.: Cho, Y.: Yun, H.: Do, J. Bull. Kor: Chem. Soc, 2005. 26. 1185.

7. Kim. Y; Yu, J.-S: Lee, C. W. Bull Kor Chem. Soc. 2000, 21. 251

8. Jhung. S. H.: Hwang. T. W. Chem. Hater 2005 . 17. 4455.

9. Chiang. R. K.: Huang. C. C.: Lin. C. R. J. Solid State Chem. 2001. 156.242 .

10. Zhao, Y. Kwon. Y.-U. Bull. Konan Chem. Soc. 2005. 26. 1271

11. Chen. X.; Zhao, Y.: Wang, R.; Li. M.: Mai. Z. Dalton 2002. 16. 3092.

12. Zhao. Y.: Ju. J.: Chet1. X.: Li. X.: Wang. R.: Mai. Z. I. Solid State Chent. 2002. 165. 182.

13. Chent. W.: Zhao. Y.: Kwon. Y.-U. Chem. Lett. 2004. 33.1616.

14. Stucky: G. D.: Philıps, M. L. F.: Gier. T. E. Chem. Mater: 1989. I. 492.

15. Philips, M. L. F; Harrison. W. T. A.; Stucky. G. D; MeCarron III. E. M:: Calabrese. J. C.: Gier. I. E. Chem. Mater 1992. f. 222.

16. Jiao. X.: Chen. D.: Hang. W: Xu. R.: Yue. Y. I. Matert Chent. 1998. 8.2831

17. Christensen, A. N.: Anderson, E. K.: Anderson. 1. G. K.: Alberli. G.; Nielsen, M.; Lehman. M. S. Acta Chem. Scand $1990,44,865$ and references therein.

18. Wloka. M.: Troyanov. S. I.: Kemnite. E. I. Solid State Chent. 2000. $1+9.21$

19. Harrison. W. T. A.: Gier. T. E.: Calabrese. J. C.: Stucky. G. D. Solid State Chem. 1994, 111, 257

20. Li. Y. J.; Whittingham, M. S. Solid State Ionics 1993, 63.391

21. Bortun, A. I.: Bortun, L. N.: Clearfield. A.: Villa-Garcia. M. A; Garcia. T. R.: Rodriguez. I. J. Mater: Res. 1996. 11. 2490.

22. Anderson. A. M. K.: Norby. P.: Vogt. T. Ihorg. Chent. 1998. 37. 4313.

23. Poojary, D. M.; Bortun. A. I.: Bortun. L. N.: Clearfield, A. J. Solid State Chem. 1997. 132.213.

24. Zhao. Y; Zhu. G.: Jiao, X; Liu. W; Hang. W. J. Mater: Chem 2000. 10.463 
25. Serre. C.: Ferey. G. J. Mater: Chem. 1999. 9.579.

26. Guo. Y.: Shi. Z.: Yu. J.: Wang. J.: Liu. Y.: Bai. N.: Pang. W. Chem. Mater. 2001. 13. 203.

27. Liu, Y.: Shi, Z.: Zhang. L.: Fu, Y. Chen. I.: Li, B.: Hua, I.: Pang, W. Chem. Hater 2001. 13. 2017.

28. Guo, Y: Shi, Z; Yu, J.: Wang. I; Liu, Y: Bai, N.: Pang, W. Chem. Mater: 2001. 13, 203

29. Fu. Y.: Liu. Y: Shi. Z.: Zou. Y: Pang. W. J. Solid State Chen. 2001. 162.96.

30. Ekambaram, S; Sevor, S. C. Angew: Chem. Int Ed 1999. 38. 372 .

31. Lin C.: Wang S. Horg. Chem. 2005. H4, 251

32. Chippindale. A. M.: Grimshaw. M. R.: Powell. A. V.: Cowley. A.
R. Inorg. Chem. 2005.4 .4121 .

33. Baes. C. F.: Mesmer. R. E. The Hydrotysis of Cationts. John Wiley \& Sons Inc: 1976

34. Serre, C.: Taulelle, F.: Ferey G. Chem. Conmm 2003. 2755.

35. Yan. W.: Yu, J.; Shi. Z; Wang, Y.: Zou, Y; Xu. R. J. Solid State Chem 2001, 161,259.

36. Ramik. R. A.: Stuman. B. D.: Dunt1. P. T.: Poverentrykh. A. S. Cam. Wineral 1980.18. 185.

37. Attfield. M. P.: Morris. R. E.: Burshtein. I: Campana. C. F.: Cheetham, A. K. J. Solid State Chem. 1995, 118, 412.

38. Lii. K. Wang. S. J. Solid State Chem 1997. 128, 21.

39. Walton. R. I.; Millage. F.: OHare. D. Chem. Hater: 2000. 12. 1977. 